\title{
Lutimonas vermicola gen. nov., sp. nov., a member of the family Flavobacteriaceae isolated from the marine polychaete Periserrula leucophryna
}

Correspondence

Jang-Cheon Cho

chojc@inha.ac.kr

\author{
Seung-Jo Yang, Yoe-Jin Choo and Jang-Cheon Cho
}

\author{
Division of Biology and Ocean Sciences, Inha University, Yonghyun-Dong, Incheon 402-751, \\ Republic of Korea
}

The family Flavobacteriaceae (Bernardet et al., 2002; Reichenbach, 1989) is one of the largest phylogenetic groups within the phylum Bacteroidetes (Garrity \& Holt, 2001). Recent polyphasic studies, including 16 S rRNA gene phylogeny, have led to a rapid increase in the description of novel members of the family Flavobacteriaceae. As a result, the family currently comprises more than 45 genera with validly published names, most of them originating from diverse saline environments. The present study focuses on the description of strain IMCC1616 ${ }^{\mathrm{T}}$, isolated from a marine polychaete dwelling in tidal flat sediment. Based on the taxonomic results collected in this study, we propose the inclusion of this isolate in a new genus and species within the family Flavobacteriaceae.

Strain IMCC $1616^{\mathrm{T}}$ was isolated from the digestive tract of a marine polychaete, Periserrula leucophryna, collected from a depth of 1-2 $\mathrm{m}$ in tidal flat sediment on Donggum island $\left(37^{\circ} 35^{\prime} 34.1^{\prime \prime} \mathrm{N} 126^{\circ} 31^{\prime} 7.5^{\prime \prime} \mathrm{E}\right)$, Korea, in July 2005 . The marine polychaete was washed with sterile seawater three times and dissected under an Olympus SZH10 stereoscopic microscope. One hundred microlitres of digestive tract homogenate was spread onto R2A agar (Difco) diluted

The GenBank/EMBL/DDBJ accession number for the 16S rRNA gene sequence of strain IMCC $1616^{\top}$ is EF108218.
$1: 10(\mathrm{v} / \mathrm{v})$ in aged seawater $(1 / 10 \mathrm{R} 2 \mathrm{~A})$ and the agar plates were incubated aerobically at $25^{\circ} \mathrm{C}$ for 15 days. Strain IMCC $1616^{\mathrm{T}}$, initially grown on $1 / 10 \mathrm{R} 2 \mathrm{~A}$, was further purified on marine agar 2216 (MA; Difco). After its optimum growth temperature was determined, cultures of strain IMCC $1616^{\mathrm{T}}$ were maintained routinely on MA at $25{ }^{\circ} \mathrm{C}$.

Cell morphology, including the presence of flagella and intracellular granules, was examined by transmission electron microscopy (CM200; Philips) study of a 5 day culture on MA at $25{ }^{\circ} \mathrm{C}$. Cell size was measured using phase-contrast and epifluorescence microscopy (Nikon 80i). For electron microscopy, exponential phase cells were washed twice with sodium cacodylate buffer and negatively stained with $2 \%$ phosphotungstic acid $(\mathrm{pH} 7.0-7.2)$ on Formvar-coated copper grids. Colony morphology, size and colour were examined from cultures grown aerobically on MA for 3 days. Anaerobic growth was tested using both the MGC anaerobic system and AnaeroPACK Anaero (Mitsubishi Gas Chemical Company). Flagellar and gliding motilities were examined using wet mounts and hanging drop preparations, respectively, made from exponentialphase cells grown on MA at $25{ }^{\circ} \mathrm{C}$ for 5 days. The growth temperature range and optimum were tested at $3-42{ }^{\circ} \mathrm{C}$. The $\mathrm{pH}$ range and optimum for growth were examined at $\mathrm{pH}$ 4.0-12.0. The $\mathrm{NaCl}$ concentration and optimum for 
growth were determined in $\mathrm{NaCl}$-free artificial seawater medium (ASW) (basic formula, $\mathrm{l}^{-1}: 19.45 \mathrm{~g} \mathrm{NaCl}, 5.9 \mathrm{~g}$ $\mathrm{MgCl}_{2} \cdot 6 \mathrm{H}_{2} \mathrm{O}, 3.24 \mathrm{~g} \mathrm{MgSO}_{4} .7 \mathrm{H}_{2} \mathrm{O}, 1.8 \mathrm{~g} \mathrm{CaCl}_{2} .2 \mathrm{H}_{2} \mathrm{O}$, $0.55 \mathrm{~g} \mathrm{KCl}, \quad 0.16 \mathrm{~g} \quad \mathrm{NaHCO}_{3}, \quad 0.08 \mathrm{~g} \quad \mathrm{KBr}, \quad 0.034 \mathrm{~g}$ $\mathrm{SrCl}_{2} .6 \mathrm{H}_{2} \mathrm{O}, 0.022 \mathrm{~g} \mathrm{H}_{3} \mathrm{BO}_{3}, 0.008 \mathrm{~g} \mathrm{Na}_{2} \mathrm{H}_{2} \mathrm{PO}_{4}, 0.004 \mathrm{~g}$ $\mathrm{Na}_{2} \mathrm{SiO}_{3}, 0.0024 \mathrm{~g} \mathrm{NaF}, 0.0016 \mathrm{~g} \mathrm{KN}_{4} \mathrm{NO}_{3}$ ), supplemented with $5.0 \mathrm{~g}$ peptone, $1.0 \mathrm{~g}$ yeast extract and various concentrations of $\mathrm{NaCl}(0-15 \%, w / v)$. The ranges of temperature, $\mathrm{pH}$ and $\mathrm{NaCl}$ concentration for growth were determined on MA or MA adjusted to various $\mathrm{pH}$ values and $\mathrm{NaCl}$ concentrations for 2 weeks. The presence of flexirubin-type pigments was determined by the bathochromatic shift test using a $20 \%(\mathrm{w} / \mathrm{v}) \mathrm{KOH}$ solution (Bernardet et al., 2002; McCammon \& Bowman, 2000). Cellular pigments of the strain were extracted with acetone/ methanol $(1: 1, \mathrm{v} / \mathrm{v})$ and their absorption spectra were determined using a scanning UV/visible spectrophotometer (Optizen 2120UV; Mechasis Co.). The catalase test was performed by addition of $3.0 \%$ hydrogen peroxide to exponential-phase colonies, and oxidase activity was determined using oxidase reagent (bioMérieux). Other biochemical tests and carbon-source utilization tests were carried out in API 20NE and API ZYM strips (bioMérieux) and in GN2 microplates (Biolog), according to the manufacturers' instructions and inoculated with bacterial suspensions in ASW. Degradation of macromolecules was tested by incubating strain IMCC $1616^{\mathrm{T}}$ on MA containing macromolecules at $25{ }^{\circ} \mathrm{C}$ for 14 days. The following macromolecules were tested: starch $(0.2 \% \mathrm{w} / \mathrm{v})$, casein $(10 \% \mathrm{w} / \mathrm{v}$ skimmed milk), elastin $(0.5 \% \mathrm{w} / \mathrm{v})$, chitin $(0.5 \% \mathrm{w} / \mathrm{v})$ and CM cellulose $(0.2 \% \mathrm{w} / \mathrm{v})$. Hydrolysis was determined by formation of clear zones around the colonies. For CM cellulose, the clear zones were revealed by flooding the colonies with a $0.1 \%$ Congo red solution and rinsing with $1 \mathrm{M} \mathrm{NaCl}$ (Teather \& Wood, 1982). Degradation of DNA was tested using DNase test agar (Difco) amended with $1.5 \% \mathrm{NaCl}$. Susceptibility to antimicrobial agents [tetracycline $(30 \mu \mathrm{g})$, ampicillin $(10 \mu \mathrm{g})$, kanamycin $(30 \mu \mathrm{g})$, chloramphenicol $(25 \mu \mathrm{g})$, erythromycin $(15 \mu \mathrm{g})$, gentamicin $(10 \mu \mathrm{g})$, penicillin $\mathrm{G}(10 \mu \mathrm{g})$, streptomycin $(10 \mu \mathrm{g})$, vancomycin $(30 \mu \mathrm{g})$ and rifampicin $(50 \mu \mathrm{g})]$ was determined using the diffusion method (Jorgensen et al., 1999). The DNA G + C content of strain IMCC $1616^{\mathrm{T}}$ was analysed by using HPLC according to Mesbah et al. (1989), with a Discovery C18 column $(5 \mu \mathrm{m}, 15 \mathrm{~cm} \times 4.6 \mathrm{~mm}$; Supelco). Cellular fatty acid methyl esters were extracted and prepared from cultures grown on MA at $25^{\circ} \mathrm{C}$ for 7 days and analysed according to the MIDI Microbial Identification System by the Korean Culture Center of Micro-organisms (KCCM).

The nearly full-length sequence of the 16S rRNA gene (1449 bp) of strain IMCC $1616^{\mathrm{T}}$ was obtained as described previously (Cho \& Giovannoni, 2003). Comparative analysis of the 16S rRNA gene sequence of the strain with sequences held in GenBank showed that it belonged to the family Flavobacteriaceae. The 16S rRNA gene sequence of the strain was aligned against more than 100 reference sequences of members of the family Flavobacteriaceae using the ARB software package (Ludwig et al., 2004), and 1208 unambiguously aligned nucleotide positions, generated using the Bacteroidetes-specific mask, were employed for phylogenetic analyses in PAUP 4.0 beta 10 (Swofford, 2002). Phylogenetic trees were inferred by three treegenerating algorithms: neighbour-joining with the Kimura two-parameter model, maximum-parsimony and


Fig. 1. Neighbour-joining phylogenetic tree, based on 16S rRNA gene sequences, show- ing relationships between strain IMCC $1616^{\top}$ and representatives of the family Flavo- bacteriaceae. Bootstrap percentages (above $50 \%$ ) from both neighbour-joining (above nodes) and maximum-parsimony (below nodes) are shown. Filled and open circles at each node respectively indicate nodes recovered by all three treeing methods or by two treeing methods. Bacteroides fragilis Bfr901 (GenBank accession no. X83945) was used as an out- group (not shown). Bar, 0.01 substitutions per nucleotide position.


maximum-likelihood. The resultant neighbour-joining and parsimony trees were evaluated by bootstrap analysis based on 1000 resamplings. Sequence comparisons based on the multiple alignment in the ARB database, Ribosomal Database Project (RDP-II) and BLASTN search results revealed that strain IMCC $1616^{\mathrm{T}}$ was only distantly related to other species in the family Flavobacteriaceae. Strain IMCC $1616^{\mathrm{T}}$ was most closely related to members of the genera Lutibacter (90.7\%), Tenacibaculum (89.2-90.4\%) and Polaribacter (88.4-90.2\%). No other species with a validly published name exceeded $90.5 \% 16 \mathrm{~S}$ rRNA gene sequence similarity with strain IMCC $1616^{\mathrm{T}}$. It formed a robust monophyletic clade with several uncultivated bacteria retrieved from marine sediments (Fig. 1). This clade formed a larger clade with Lutibacter litoralis; however, this relationship was not supported by bootstrap analysis. Comprehensive phylogenetic analyses revealed that the strain could not be associated with any of the known genera in the family. Therefore, strain IMCC $1616^{\mathrm{T}}$ was considered to represent a new genus in the family Flavobacteriaceae.

The phenotypic and biochemical characteristics of strain IMCC $1616^{\mathrm{T}}$ are listed in the genus and species descriptions and in Tables 1 and 2. Cells of strain IMCC $1616^{\mathrm{T}}$ were Gram-negative, chemoheterotrophic, non-motile, strictly aerobic and rod-shaped. The DNA G +C content (40.1 mol\%) and several phenotypic characteristics, including growth temperature and catalase activity, differentiated the strain from other related genera in the family Flavobacteriaceae (Table 1). The predominant cellular fatty acids of the strain were iso- $\mathrm{C}_{15: 0}(16.5 \%)$, anteiso- $\mathrm{C}_{15: 0}(10.9 \%)$, iso- $\mathrm{C}_{17: 0} 3-\mathrm{OH}(8.8 \%)$ and iso$\mathrm{C}_{17: 1} \omega 9 c(8.2 \%)$, in agreement with other related genera

Table 1. Differential phenotypic characteristics of strain IMCC $1616^{\top}$ and other related genera in the family Flavobacteriaceae

Taxa: 1, IMCC1616 ${ }^{\mathrm{T}}$ (data from this study); 2, Lutibacter (data from Choi \& Cho, 2006); 3, Polaribacter (Gosink et al., 1998; Nedashkovskaya et al., 2005; Yoon et al., 2006); 4, Tenacibaculum (Choi et al., 2006; Frette et al., 2004; Hansen et al., 1992; Jung et al., 2006; Suzuki et al., 2001; Wakabayashi et al., 1986; Yoon et al., 2005); 5, Krokinobacter (Khan et al., 2006). +, Positive ; -, negative; w, weak reaction; v, variable; ND, no data available.

\begin{tabular}{|c|c|c|c|c|c|}
\hline Characteristic & 1 & 2 & 3 & 4 & 5 \\
\hline Cell shape & Rod & Rod & $\begin{array}{l}\text { Rod, spiral, } \\
\text { filamentous }\end{array}$ & Rod & Rod \\
\hline Colony colour & Yellow & Yellow & Yellow or orange & Yellow & Yellow \\
\hline Gliding motility & - & - & - & $\mathrm{V}^{*}$ & ND \\
\hline Growth at $4{ }^{\circ} \mathrm{C}$ & + & + & + & $\mathrm{V}$ & - \\
\hline Growth at $37{ }^{\circ} \mathrm{C}$ & + & - & - & $\mathrm{v}$ & - \\
\hline Oxidase activity & - & - & $\mathrm{v}^{\dagger}$ & + & + \\
\hline Catalase activity & - & + & + & + & + \\
\hline Nitrate reduction & - & - & $\mathrm{V} \ddagger$ & $\mathrm{v}$ & - \\
\hline Acid production from glucose & - & - & $\mathrm{v}$ & $\mathrm{V}$ & - \\
\hline$\beta$-Galactosidase activity & $v \S$ & $\mathrm{W}$ & $\mathrm{v}$ & $-{ }^{a} \|$ & + \\
\hline \multicolumn{6}{|l|}{ Hydrolysis of: } \\
\hline Starch & + & + & + & $\mathrm{v}$ & - \\
\hline Gelatin & + & + & $\mathrm{V}$ & +9 & + \\
\hline Chitin & - & $\mathrm{ND}$ & - & $\mathrm{v}$ & - \\
\hline \multicolumn{6}{|l|}{ Carbon utilization: } \\
\hline Tween 80 & - & - & $+{ }^{b}$ & $\mathrm{v}$ & + \\
\hline D-Fructose & + & + & $\mathrm{v}$ & $-^{d}$ & + \\
\hline D-Galactose & + & - & $--^{c}$ & $-{ }^{d}$ & ND \\
\hline Glycerol & + & - & $\mathrm{v}$ & $\mathrm{V}$ & - \\
\hline Sucrose & + & - & $\mathrm{v}$ & $\mathrm{v}$ & + \\
\hline DNA $G+C$ content $(\mathrm{mol} \%)$ & 40.1 & 33.9 & $30-33$ & $30-35.2$ & $33-39$ \\
\hline
\end{tabular}

${ }^{*}$ All species positive except T. skagerrakense.

$\dagger$ All species positive except P. filamentus.

‡All species negative except $P$. glomeratus.

§Positive in API 20NE strips (substrate $p$-nitrophenyl $\beta$-D-galactopyranoside) but negative in API ZYM system (substrate 2-naphthyl $\beta$-D-galactopyranoside).

IIData available for the following species only: $a$, T. aestuarii and T. litoreum; $b$, P. butkevichii and P. dokdonensis; c, P. dokdonensis; $d, T$. aestuarii, T. litoreum and T. lutimaris.

SData not available for T. skagerrakense. 
Table 2. Cellular fatty acid compositions (\%) of strain IMCC $1616^{\top}$ and other related genera in the family Flavobacteriaceae.

Taxa: 1, IMCC1616 ${ }^{\mathrm{T}}$ (data from this study); 2, Lutibacter (Choi \& Cho, 2006); 3, Polaribacter (data for P. butkevichii, P. dokdonensis, P. filamentus, P. franzmannii and P. irgensii from Gosink et al., 1998; Nedashkovskaya et al., 2005; Yoon et al., 2006); 4, Tenacibaculum (data for T. aestuarii, T. litoreum, T. lutimaris, T. maritimum, T. mesophilum and T. skagerrakense from Choi et al., 2006; Jung et al., 2006; Yoon et al., 2005); 5, Krokinobacter (Khan et al., 2006). -, Not detected/not reported. Only fatty acids amounting to at least $5 \%$ of the total cellular fatty acids of at least one of the species are shown. All species studied were grown on MA except Polaribacter species.

\begin{tabular}{|c|c|c|c|c|c|}
\hline Fatty acid & 1 & 2 & 3 & 4 & 5 \\
\hline iso $-\mathrm{C}_{13: 0}$ & 1.0 & - & $2-16.4$ & $0.2-1.8$ & - \\
\hline $\mathrm{C}_{15: 0}$ & 3.8 & 1.7 & $2.3-8.1^{*}$ & $2.7-8.9$ & - \\
\hline iso- $\mathrm{C}_{15: 0}$ & 16.5 & 16.7 & $9-22$ & $9.5-18.9$ & $13-22$ \\
\hline anteiso- $\mathrm{C}_{15: 0}$ & 10.9 & 15.1 & $4-6^{a_{\dagger}}$ & $0.7-1.8^{b}$ & $5-8$ \\
\hline $\mathrm{C}_{15: 1} \omega 6 c$ & 1.4 & 1.5 & $3-9$ & $1.6-4.2^{b}$ & - \\
\hline iso- $\mathrm{C}_{15: 1}$ & 6.7 & 4.0 & $6-15.4^{c}$ & $5.3-8.7$ & $15-26$ \\
\hline anteiso- $\mathrm{C}_{15: 1}$ & 1.0 & 1.6 & - & - & $3-6$ \\
\hline iso- $\mathrm{C}_{16: 0}$ & 2.5 & - & - & $0.3-3.8$ & $2-4$ \\
\hline iso- $\mathrm{C}_{17: 1} \omega 9 c$ & 8.2 & - & - & $0.4-1.6^{d}$ & - \\
\hline iso- $\mathrm{C}_{15: 0} 3-\mathrm{OH}$ & 3.2 & 17.4 & $12-38$ & $4.6-19.8$ & 3.0 \\
\hline iso- $\mathrm{C}_{16: 0} 3-\mathrm{OH}$ & 3.1 & 13.4 & $5.0 \ddagger$ & $5-12.8$ & $5-12$ \\
\hline iso- $\mathrm{C}_{17: 0} 3-\mathrm{OH}$ & 8.8 & 3.9 & $8.4 末$ & $8.4-14.9$ & $6-10$ \\
\hline Summed feature $3 \S$ & 7.1 & 1.0 & $6.6 \ddagger$ & $11.9-24.4$ & - \\
\hline
\end{tabular}

${ }^{\star}$ Detected only in P. butkevichii and P. dokdonensis.

$\dagger$ Not detected in the following species: a, P. butkevichii and P. dokdonensis; b, T. skagerrakense; $c$, P. butkevichii; $d, T$. maritimum and T. skagerrakense.

$\ddagger$ Detected only in $P$. dokdonensis.

§Comprising $\mathrm{C}_{16: 1} \omega 7 c$ and/or iso- $\mathrm{C}_{15: 0} 2-\mathrm{OH}$.

in the family, except for the proportion of iso- $\mathrm{C}_{17: 1} \omega 9 c$ (Table 2).

As shown by the low 16S rRNA gene sequence similarity $(<91 \%)$ with other taxa, the formation of an independent phyletic line in the phylogenetic tree and differential phenotypic characteristics, strain IMCC $1616^{\mathrm{T}}$ cannot be assigned to any of the known genera in the family Flavobacteriaceae. Therefore it should be classified as representing a novel species in a new genus, for which the name Lutimonas vermicola gen. nov., sp. nov. is proposed.

\section{Description of Lutimonas gen. nov.}

Lutimonas (Lu.ti.mo'nas. L. n. lutum mud; L. fem. n. monas a unit; N.L. fem. n. Lutimonas a unit from mud, pertaining to the habitat of the animal that harboured the type species, a marine tidal flat).

Cells are Gram-negative, non-motile, strictly aerobic rods. Carotenoid pigments are present, flexirubin-type pigments are absent. Chemoheterotrophic. $\mathrm{NaCl}$ is required for growth. Catalase- and oxidase-negative. The major fatty acids are iso- $\mathrm{C}_{15: 0}$, anteiso- $\mathrm{C}_{15: 0}$, iso- $\mathrm{C}_{17: 0} 3-\mathrm{OH}$ and iso$\mathrm{C}_{17: 1} \omega 9 \mathrm{c}$. The DNA G+C content of the type species is $40.1 \pm 0.5 \mathrm{~mol} \%$. The genus belongs to the family Flavobacteriaceae. The type species is Lutimonas vermicola.

\section{Description of Lutimonas vermicola sp. nov.}

Lutimonas vermicola (ver.mi'co.la. L. n. vermis worm; L. suff. - cola from L. n. incola inhabitant; N.L. n. vermicola inhabitant of worms, pertaining to the origin of the type strain, a marine polychaete).

The description of the species conforms to that of the genus. Cells are 1.6-2.5 $\mu \mathrm{m}$ long and $0.7-1.0 \mu \mathrm{m}$ wide. Devoid of flagellar and gliding motilities. After 3 days of incubation, colonies on MA are circular, pulvinate, entire, smooth, opaque, yellow-coloured and $1.0-3.0 \mathrm{~mm}$ in diameter. Growth occurs at $3-37{ }^{\circ} \mathrm{C}$ (optimum, $25{ }^{\circ} \mathrm{C}$ ), at $\mathrm{pH} 5-11$ (optimum, $\mathrm{pH} 8$ ) and with $0.5-7.5 \% \mathrm{NaCl}$ (optimum, 1.5-2.5\%). Absorption spectral peaks of the carotenoid pigments are observed at 427, 453 (major peak) and $478 \mathrm{~nm}$. Degrades starch and gelatin, but not elastin, $\mathrm{CM}$ cellulose or chitin. Does not grow on DNase agar or MA containing casein. In API 20NE strips, positive for $\beta$-galactosidase activity (substrate, $p$-nitrophenyl $\beta$-Dgalactopyranoside). Negative for urease, gelatin liquefaction and arginine dihydrolase. Indole is not produced. Acid is not produced from glucose. Nitrate is not reduced. In the API ZYM system, alkaline phosphatase, esterase (C4), esterase lipase (C8), leucine arylamidase, valine arylamidase, cystine arylamidase, acid phosphatase, $\beta$-glucosidase, $\quad N$-acetyl- $\beta$-glucosaminidase and $\alpha$-mannosidase 
activities are present, but lipase (C14), trypsin, $\alpha$-chymotrypsin, naphthol-AS-BI-phosphohydrolase, $\beta$-galactosidase (substrate, 2 -naphthyl $\beta$-D-galactopyranoside), $\beta$ glucuronidase, $\alpha$-glucosidase and $\alpha$-fucosidase activities are absent. Weakly positive for $\alpha$-galactosidase activity. Utilizes the following carbon substrates in Biolog GN2 microplates: $\alpha$-cyclodextrin, glycogen, $N$-acetyl-D-galactosamine, $N$-acetyl-D-glucosamine, D-cellobiose, i-erythritol, $\mathrm{D}$-fructose, L-fucose, D-galactose, gentiobiose, $\alpha$-D-glucose, myo-inositol, $\alpha$-D-lactose, lactulose, maltose, D-mannose, D-melibiose, methyl $\beta$-D-glucoside, D-psicose, D-raffinose, L-rhamnose, D-sorbitol, sucrose, D-trehalose, turanose, xylitol, succinic acid monomethyl ester, acetic acid, cis-aconitic acid, citric acid, D-galacturonic acid, D-glucosaminic acid, Dglucuronic acid, $\alpha$-hydroxybutyric acid, $\beta$-hydroxybutyric acid, $\gamma$-hydroxybutyric acid, $\alpha$-ketoglutaric acid, DL-lactic acid, succinic acid, bromosuccinic acid, succinamic acid, glucuronamide, L-alaninamide, D-alanine, L-alanine, L-alanyl glycine, L-asparagine, L-aspartic acid, L-glutamic acid, glycyl L-aspartic acid, glycyl L-glutamic acid, L-histidine, hydroxyL-proline, L-ornithine, L-proline, L-threonine, $\gamma$-aminobutyric acid, inosine, uridine, thymidine, phenyl ethylamine, putrescine, 2-aminoethanol, 2,3-butanediol, glycerol, DL- $\alpha$ glycerol phosphate, $\alpha$-D-glucose 1-phosphate and D-glucose 6-phosphate. Does not utilize dextrin, Tween 40, Tween 80, adonitol, L-arabinose, D-arabitol, D-mannitol, pyruvic acid methyl ester, formic acid, D-galactonic acid, D-gluconic acid, $p$-hydroxyphenylacetic acid, itaconic acid, $\alpha$-ketobutyric acid, $\alpha$-ketovaleric acid, malonic acid, propionic acid, quinic acid, D-saccharic acid, sebacic acid, L-leucine, L-phenylalanine, L-pyroglutamic acid, D-serine, L-serine, DL-carnitine or urocanic acid. Susceptible to rifampicin, vancomycin, erythromycin, penicillin $\mathrm{G}$, tetracycline and chloramphenicol, but resistant to ampicillin, gentamicin, kanamycin and streptomycin. In addition to the major cellular fatty acids reported in Table 2, the following fatty acids are present in minor proportions: anteiso- $\mathrm{C}_{17: 1} \omega 9 c(3.0 \%)$, unknown ECL $13.565(2.9 \%), \mathrm{C}_{17: 1} \omega 6 c(2.7 \%), \mathrm{C}_{17: 0} 2-\mathrm{OH}(2.6 \%), \mathrm{C}_{15: 0}$ $2-\mathrm{OH}(2.5 \%), \mathrm{C}_{15: 1} 2-\mathrm{OH}(2.2 \%)$, iso- $\mathrm{C}_{17: 1} \mathrm{I}$ and/or anteiso- $\mathrm{C}_{17: 1} \mathrm{~B}(1.2 \%)$ and iso- $\mathrm{C}_{14: 0}(1.0 \%)$. Traces $(<1 \%)$ of the following fatty acids are also present: $\mathrm{C}_{16: 0}$, $\mathrm{C}_{17: 1} \omega 8 c$, unknown ECL 16.582, anteiso- $\mathrm{C}_{13: 0}$, iso- $\mathrm{C}_{17: 0}$, $\mathrm{C}_{18: 1} \omega 5 c$, anteiso- $\mathrm{C}_{17: 0}, \mathrm{C}_{17: 0} 3-\mathrm{OH}$, iso- $\mathrm{C}_{14: 1} \mathrm{~B}$, iso- $\mathrm{C}_{14: 0}$ 3-OH, $\mathrm{C}_{18: 0}$, unknown ECL 11.543, $\mathrm{C}_{16: 0} 3-\mathrm{OH}, \mathrm{C}_{17: 0}$, $\mathrm{C}_{19: 0}$ and iso- $\mathrm{C}_{11: 0}$.

The type strain is IMCC $1616^{\mathrm{T}}\left(=\mathrm{KCCM} 42379^{\mathrm{T}}=\mathrm{NBRC}\right.$ $\left.102041^{\mathrm{T}}\right)$, isolated from the digestive tract of a polychaete (Periserrula leucophryna) inhabiting a tidal flat of Donggum island, Korea.

\section{Acknowledgements}

The authors are grateful to Dr Jae-Sang Hong for his assistance in the collection of marine worms. We acknowledge the great efforts of two anonymous reviewers and the editor, whose comments significantly improved this paper. This study was supported by the 21C Frontier program of Microbial Genomics and Applications (grant MG05-01021-0) from the Ministry of Science and Technology, Republic of Korea.

\section{References}

Bernardet, J. F., Nakagawa, Y. \& Holmes, B. (2002). Proposed minimal standards for describing new taxa of the family Flavobacteriaceae and emended description of the family. Int J Syst Evol Microbiol 52, 1049-1070.

Cho, J. C. \& Giovannoni, S. J. (2003). Croceibacter atlanticus gen. nov., sp. nov., a novel marine bacterium in the family Flavobacteriaceae. Syst Appl Microbiol 26, 76-83.

Choi, D. H. \& Cho, B. C. (2006). Lutibacter litoralis gen. nov., sp. nov., a marine bacterium of the family Flavobacteriaceae isolated from tidal flat sediment. Int J Syst Evol Microbiol 56, 771-776.

Choi, D. H., Kim, Y. G., Hwang, C. Y., Yi, H., Chun, J. \& Cho, B. C. (2006). Tenacibaculum litoreum sp. nov., isolated from tidal flat sediment. Int J Syst Evol Microbiol 56, 635-640.

Frette, L., Jørgensen, N. O. G., Irming, H. \& Kroer, N. (2004). Tenacibaculum skagerrakense sp. nov., a marine bacterium isolated from the pelagic zone in Skagerrak, Denmark. Int J Syst Evol Microbiol 54, 519-524.

Garrity, G. M. \& Holt, J. G. (2001). The road map to the Manual. In Bergey's Manual of Systematic Bacteriology, 2nd edn, vol. 1, pp. 119-166. Edited by D. R. Boone, R. W. Castenholz \& G. M. Garrity. New York: Springer.

Gosink, J. J., Woese, C. R. \& Staley, J. T. (1998). Polaribacter gen. nov., with three new species, $P$. irgensii sp. nov., $P$. franzmannii sp. nov. and $P$. filamentus sp. nov., gas vacuolate polar marine bacteria of the Cytophaga-Flavobacterium-Bacteroides group and reclassification of 'Flectobacillus glomeratus' as Polaribacter glomeratus comb. nov. Int J Syst Bacteriol 48, 223-235.

Hansen, G. H., Bergh, Ø., Michaelsen, J. \& Knappskog, D. (1992). Flexibacter ovolyticus sp. nov., a pathogen of eggs and larvae of Atlantic halibut, Hippoglossus hippoglossus L. Int J Syst Bacteriol 42, 451-458.

Jorgensen, J. H., Turnidge, J. D. \& Washington, J. A. (1999). Antibacterial susceptibility tests: dilution and disk diffusion methods. In Manual of Clinical Microbiology, pp. 1526-1543. Edited by P. R. Murray, E. J. Baron, M. A. Pfaller, F. C. Tenover \& R. H. Yolken. Washington, DC: American Society for Microbiology.

Jung, S. Y., Oh, T. K. \& Yoon, J. H. (2006). Tenacibaculum aestuarii sp. nov., isolated from a tidal flat sediment in Korea. Int J Syst Evol Microbiol 56, 1577-1581.

Khan, S. T., Nakagawa, Y. \& Harayama, S. (2006). Krokinobacter gen. nov., with three novel species, in the family Flavobacteriaceae. Int $J$ Syst Evol Microbiol 56, 323-328.

Ludwig, W., Strunk, O., Westram, R., Richter, L., Meier, H., Yadhukumar, Buchner, A., Lai, T., Steppi, S. \& other authors (2004). ARB: a software environment for sequence data. Nucleic Acids Res 32, 1363-1371.

McCammon, S. A. \& Bowman, J. P. (2000). Taxonomy of Antarctic Flavobacterium species: description of Flavobacterium gillisiae sp. nov., Flavobacterium tegetincola sp. nov. and Flavobacterium xanthum sp. nov., nom. rev. and reclassification of [Flavobacterium] salegens as Salegentibacter salegens gen. nov., comb. nov. Int J Syst Evol Microbiol 50, 1055-1063.

Mesbah, M., Premachandran, U. \& Whitman, W. B. (1989). Precise measurement of the $\mathrm{G}+\mathrm{C}$ content of deoxyribonucleic acid by high-performance liquid chromatography. Int J Syst Bacteriol 39, 159-167.

Nedashkovskaya, O. I., Kim, S. B., Lysenko, A. M., Kalinovskaya, N. I., Mikhailov, V. V., Kim, I. S. \& Bae, K. S. (2005). Polaribacter butkevichii sp. nov., a novel marine mesophilic bacterium of the family Flavobacteriaceae. Curr Microbiol 51, 408-412. 
Reichenbach, H. (1989). Order I. Cytophagales Leadbetter 1974, $99^{\mathrm{AL}}$. In Bergey's Manual of Systematic Bacteriology, vol. 3, pp. 2011-2013. Edited by J. T. Staley, M. P. Bryant, N. Pfennig \& J. G. Holt. Baltimore: Williams \& Wilkins.

Suzuki, M., Nakagawa, Y., Harayama, S. \& Yamamoto, S. (2001). Phylogenetic analysis and taxonomic study of marine Cytophaga-like bacteria: proposal for Tenacibaculum gen. nov. with Tenacibaculum maritimum comb. nov. and Tenacibaculum ovolyticum comb. nov., and description of Tenacibaculum mesophilum sp. nov. and Tenacibaculum amylolyticum sp. nov. Int J Syst Evol Microbiol 51, 1639-1652.

Swofford, D. L. (2002). PAUP ${ }^{*}$ : phylogenetic analysis using parsimony ( ${ }^{\star}$ and other methods), version 4. Sunderland, MA: Sinauer Associates.
Teather, R. M. \& Wood, P. J. (1982). Use of Congo red-polysaccharide interactions in enumeration and characterization of cellulolytic bacteria from the bovine rumen. Appl Environ Microbiol 43, 777-780.

Wakabayashi, H., Hikida, M. \& Masumura, K. (1986). Flexibacter maritimus sp. nov., a pathogen of marine fishes. Int J Syst Bacteriol 36, 396-398.

Yoon, J. H., Kang, S. J. \& Oh, T. K. (2005). Tenacibaculum lutimaris sp. nov., isolated from a tidal flat in the Yellow Sea, Korea. Int J Syst Evol Microbiol 55, 793-798.

Yoon, J. H., Kang, S. J. \& Oh, T. K. (2006). Polaribacter dokdonensis sp. nov., isolated from seawater. Int J Syst Evol Microbiol 56, 1251-1255. 